\title{
Genetic diversity and divergence applied to Enviromental services for Araucaria angustifolia (Brazil)
}

\author{
Luciano Medina-Macedo $^{1 *}$, Juliana Bittencourt ${ }^{2}$, Carlos Soccol ${ }^{1}$, Andre Lacerda ${ }^{3}$ \\ From IUFRO Tree Biotechnology Conference 2011: From Genomes to Integration and Delivery \\ Arraial d'Ajuda, Bahia, Brazil. 26 June - 2 July 2011
}

Humans derive many utilitarian benefits from the environmental services of biotas and ecosystems. Yet ecosystem, species and genetic levels is increasingly lost from agricultural landscapes mainly due to maximisation of production $[1,2]$. The genetic variability is a result of several forces including mutation, recombination and gene flow. Allele frequencies are altered by natural selection and by genetic drift. Whilst mutation, recombination and genetic drift are random and independent processes, natural selection is a directional process towards evolutionary change [3]. The Araucaria Rainforest is one of the most important biomes occurring naturally in southern Brazil. The extensive logging and agricultural expansion became this forest extremely fragmented. Particularly important is the factor of ecosystem resilience, which appears to underpin many of the services. While biodiversity often plays a key role, the services can also derive from biomass and other attributes of biotas, for example, genetic diversity of a particular species. Landscape genetics are being used in this project to improve the understanding of fragmentation impact to assist an environmental services scheme. The objective of this study was to assess by microsatellites markers, the genetic diversity and dynamics in remnant patches of Araucaria angustifolia rainforest, with different levels of human modification. The project compared two different forest conditions: one is $1.157,48$ ha of continuous forest, and the other is a fragmented forest remnant, with size from 8 ha, appraised $5 \mathrm{~km}$ from the continuous forest area. Genetic diversity and divergence of seedlings and adult individuals present in forest

\footnotetext{
* Correspondence: medinacwb@hotmail.com

'Biotechnological Processes, Federal University of Parana, Curitiba, Parana, 81531-990, Brazil

Full list of author information is available at the end of the article
}

fragment was compared with the genetic composition of samples appraised in continuous forest. Cambium and seed material were collected from each recorded tree, and genomic DNA was extracted using the method described in Mazza \& Bittencourt (2000). The seeds for DNA extraction had undergone a slight adjustment Proteinase $\mathrm{K}$ was added to megagametophyte (maternal origin) and embryo extraction. Polymerase chain reaction (PCR) conditions used were establish by Qiagen Multiplex Master Mix protocol (1022830) and use fluorescents dye labelling. Two multiplexed systems of microsatellites were applied with the 8 primers. The eight loci used were CRCAc2, Ag23, Ag62, Ag45, CRCAc1, Ag20, Ag56 and As90. Following PCR this dilution was running in $A B I$ sequencer 3100 . Gene Scan and Genotyper software were used for data collection and alleles analysis. The average number of alleles per locus among adult trees in the continuous forest was 8.10, compared to 5.15 appraised in forest fragment. The means of expected heterozygosity were 0.623 for continuous forest and 0.579 for forest fragment, while observed heterozygosity range was respectively, 0.571 and 0.723 . Subpopulations of forest fragments were more distinguished than subpopulations of continuous, due the average fixation index was 0.082 for subpopulations in the continuous forest and 0.210 in fragment. It is worth noting that the levels of genetic differentiation among all subpopulations can be considered to be high. Paternity analysis, within the continuous forest indicated that $48 \%$ of offspring were fertilized by pollen from trees outside the plot site. The average pollination distance within the continuous was $95 \mathrm{~m}$. In the trees from forest fragment, the analysis showed that $42 \%$ to $65 \%$ of the offspring was fertilized by pollen from trees outside fragment. The effective number of pollen donors in the 
continuous forest ranged among seed-trees from 2 to 10 , and in the fragment from 2 to 6 . The results suggest high pollen dispersal distance in both conditions and an absence of reproductive isolation. They also show high pollen immigration and dispersal distance among the tree groups. The results suggest that fragmentation increases divergence in Araucaria angustifolia. The population in continuous forest showed higher genetic diversity in the adult population than the population of trees in fragment. The reducing the heterozygosity were low, may be due the recent forest fragmentation history. There are more inbreeding in fragmented population than in continuous population. Fragmentation increased the genetic divergence among the fragmented population. However, the genetic results indicated the presence of long-distance dispersal leading to functional connectivity between isolated forest fragment. The survival of remnants of Araucaria angustifolia patches as well as single trees in the agricultural landscape is key factors for species conservation and could be applied to environmental payment services, these strategy for $A$. angustifolia is an integration of conservation strategies across reserves and the surrounding matrix, including productive agricultural areas, to assist gene flow movement between temporally suitable habitats.

\section{Acknowledgements}

EMBRAPA Florestas, UTFPR Campus Ponta Grossa and Post Graduate

Program in Biotechnological Processes UFPR

\section{Author details}

'Biotechnological Processes, Federal University of Parana, Curitiba, Parana, 81531-990, Brazil. ${ }^{2}$ Federal Technological University of Parana, Ponta Grossa Parana, 84016-210, Brazil. ${ }^{3}$ EMBRAPA FLORESTAS, Colombo, Parana, 83411 000, Brazil.

Published: 13 September 2011

\section{References}

1. Millennium Ecosystem Assessment. Ecosystems and human well-being: General synthesis Washington, DC: Island Press; 2005.

2. Swinton SM, Lupi F, Robertson GP, Landis DA: Ecosystem services from agriculture: looking beyond the usual suspects. American Journal of Agricultural Economics 2006, 5:1160-1166.

3. Lindenmayer DB, Franklin JF: Conservation forest biodiversity: comprehensive multiscale approach. Washington: Island Press; 2002.

\section{doi:10.1186/1753-6561-5-S7-P9}

Cite this article as: Medina-Macedo et al:: Genetic diversity and divergence applied to Enviromental services for Araucaria angustifolia (Brazil). BMC Proceedings 2011 5(Suppl 7):P9.

\section{Submit your next manuscript to BioMed Central} and take full advantage of:

- Convenient online submission

- Thorough peer review

- No space constraints or color figure charges

- Immediate publication on acceptance

- Inclusion in PubMed, CAS, Scopus and Google Scholar

- Research which is freely available for redistribution

Submit your manuscript at www.biomedcentral.com/submit 